\title{
Identification of deep subaqueous co-seismic scarps through specific coeval sedimentation in Lesser Antilles: implication for seismic
} hazard

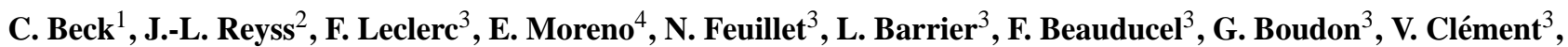

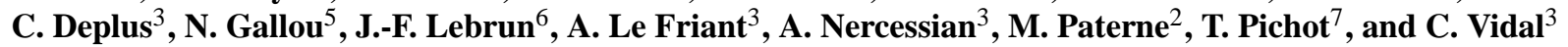 \\ ${ }^{1}$ ISTerre, UMR CNRS 5275, Grenoble University, 73376 Le Bourget du Lac cedex, France \\ ${ }^{2}$ L.S.C.E., UMR CEA/CNRS 8212, avenue de la Terrasse, 91198, Gif-sur-Yvette Cedex, France \\ ${ }^{3}$ Laboratoire de Tectonique, UMR CNRS 7578, I.P.G. de Paris, 4, Place Jussieu, 75252 Paris cedex 05, France \\ ${ }^{4}$ Sciences de la Terre, USM 203, M.N.H.N., rue Buffon, 75005 Paris, France \\ ${ }^{5}$ Vert-Pré 97231 Le Robert, France \\ ${ }^{6}$ Laboratoire de Recherche en Géosciences, UMR CNRS 8053, Universitédes Antilles et de la Guyane, Pointe-à-Pitre, France \\ ${ }^{7}$ Laboratoire de Géodynamique et Géophysique, IFREMER, BP 70, 29280 Plouzané, France
}

Correspondence to: C. Beck (beck@univ-savoie.fr)

Received: 13 September 2011 - Revised: 23 February 2012 - Accepted: 23 February 2012 - Published: 29 May 2012

\begin{abstract}
During the GWADASEIS cruise (Lesser Antilles volcanic arc, February-March 2009) a very high resolution (VHR) seismic-reflection survey was performed in order to constrain Late Quaternary to Present faulting. The profiles we obtained evidence frequent "ponding" of reworked sediments in the deepest areas, similar to the deposition of Mediterranean "homogenites". These bodies are acoustically transparent (few ms t.w.t. thick) and are often deposited on the hanging walls of dominantly normal faults, at the base of scarps. Their thickness appears sufficient to compensate (i.e. bury) co-seismic scarps between successive earthquakes, resulting in a flat and horizontal sea floor through time. In a selected area (offshore Montserrat and Nevis islands), piston coring ( 4 to $7 \mathrm{~m}$ long) was dedicated to a sedimentological analysis of the most recent of these particular layers. It corresponds to non-stratified homogenous calcareous silty sand (reworked calcareous plankton and minor volcanoclastics). This layer can be up to $2 \mathrm{~m}$ thick, and overlies finegrained hemipelagites. The upper centimeters of the latter represent the normal RedOx water/sediment interface. ${ }^{210} \mathrm{~Pb}$ and ${ }^{137} \mathrm{Cs}$ activities lack in the massive sands, while a normal profile of unsupported ${ }^{210} \mathrm{~Pb}$ decrease is observed in the hemipelagite below, together with a ${ }^{137} \mathrm{Cs}$ peak corresponding to the Atmospheric Nuclear Experiments (1962). The RedOx level was thus capped by a recent instantaneous major sedimentary event considered as post-1970 AD; candidate
\end{abstract}

seismic events to explain this sedimentary deposits are either the 16 March 1985 earthquake or the 8 October 1974 one $\left(M_{\mathrm{w}}=6.3\right.$ and $M_{\mathrm{w}}=7.4$, respectively). This leads to consider that the syntectonic sedimentation in this area is not continuous but results from accumulation of thick homogenites deposited after the earthquakes (as observed in the following weeks after Haiti January 2010 event, McHugh et al., 2011). The existence of such deposits suggests that, in the area of study, vertical throw likely results from cumulated effects of separated earthquakes rather than from aseismic creep. Examination of VHR profiles shows that all major co-seismic offsets are recorded in the fault growth sequence and that co-seismic offsets can be precisely estimated. By using a sedimentation rate deduced from ${ }^{210} \mathrm{~Pb}$ decrease curve $\left(0.5 \mathrm{~mm} \mathrm{yr}^{-1}\right)$ and taking into account minor reworking events detected in cores, we show that the Redonda system may have been responsible for five $>M_{6}$ events during the last $34000 \mathrm{yr}$.

The approach presented in this work differs from fault activity analyses using displaced sets of isochronous surfaces and postulating co-seismic offsets. Combining VHR seismic imagery and coring we can decipher co-seismic vs. slow continuous displacement, and thus actually estimate the amplitude and the time distribution of major co-seismic offsets. 


\section{Introduction}

The Lesser Antilles volcanic arc results from the convergence between the Caribbean and American plates at a rate of about $2 \mathrm{~cm} \mathrm{yr}^{-1}$ (Minster and Jordan, 1978; Demets et al., 2000; Lopez et al., 2006) (Fig. 1). The Caribbean (upper) plate deforms in response to slip partitioning of the oblique convergence between the two plates (Feuillet et al., 2002, 2010). This deformation is accommodated by several active faults that crosscut all the islands of the arc between Martinique and Nevis (Feuillet et al., 2002, 2004, 2010). The overall geometry of the fault system is an arc-scale leftlateral horsetail, composed of an arc-parallel en échelon fault system connected with several arc-perpendicular graben in its outer part. These faults (with superficial ruptures and few $\mathrm{km}$-deep foci) result in a high seismic hazard for the islands of the arc. This is clearly highlighted by the two damaging earthquakes which occurred during the last $25 \mathrm{yr}$ : on 16 March 1985 in Nevis and on 21 November 2004 in Les Saintes in Guadeloupe (Fig. 1, Feuillet et al., 2011a).

The GWADASEIS project was motivated by the occurrence of the Les Saintes 2004 earthquake and was designed to understand the kinematics of the great en-échelon system at different times and scales. Very high resolution (VHR) seismic profiles (Chirp/3.5 kHz) and piston cores were acquired in order to reconstruct the seismic history of fault growth in recent times (Late Quaternary and Holocene), and to contribute to the assessment of the seismic hazard in the Lesser Antilles arc. Although limited examples of application of this submarine paleoseismological approach exist, important and good cases come from the Marmara Sea and New Zealand (e.g. Armijo et al., 2005; Bull et al., 2006; Beck et al. 2007; Barnes and Pondard 2010).

\section{Data acquisition and laboratory measurements}

The GWADASEIS cruise was conducted between 23 February and 27 March 2009 onboard R/V LE SUROITT (IFREMER-GENAVIR) starting from Guadeloupe Island. The cruise was divided into two legs:

- a first one dedicated to the acquisition of multichannel high resolution seismic profiles and $3.5 \mathrm{khz} /$ Chirp profiles perpendicular to the en échelon fault system from St. Lucia to Saba. We also acquired EM300 multibeam bathymetry;

- a second one dedicated to the acquisition of very high resolution (VHR) sea floor imagery with a long range side scan sonar (SAR) and gravity pistoncoring (Küllenberg-type).

Coring sites were selected based on a preliminary shipboard analysis of $3.5 \mathrm{kHz}$ profiles (see profiles locations and coring sites on Fig. 2). 17 cores (with $10 \mathrm{~cm}$ internal diameter) were

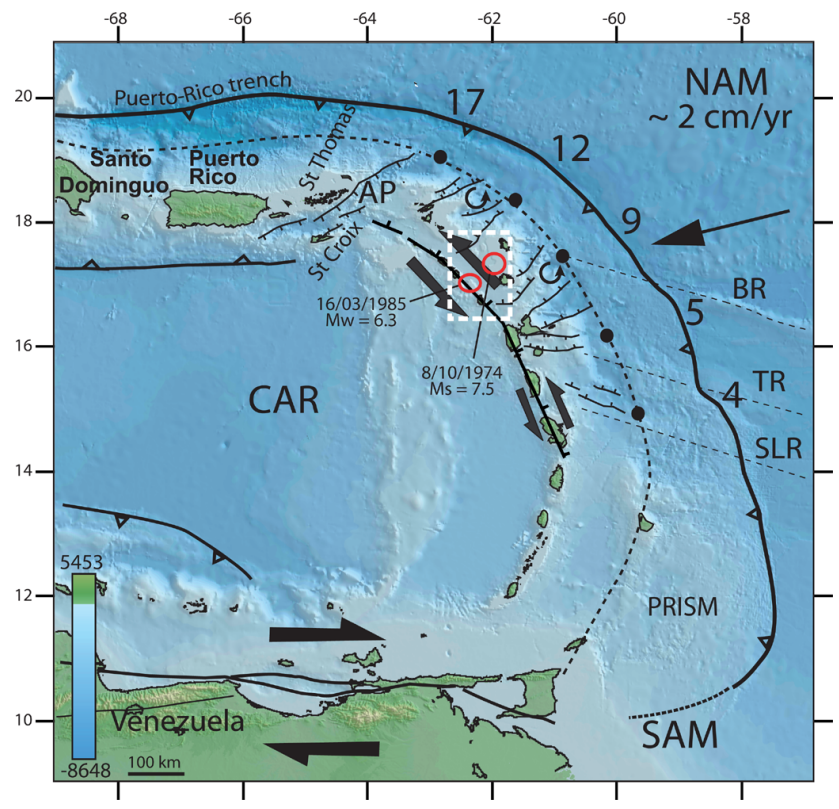

Fig. 1. Major active tectonic structures of the Lesser Antilles Arc (modified after Feuillet et al., 2011b and from Lopez et al. (2006). NAM: North America Plate; SAM: South America Plate; CAR: Caribbean Plate; AP: Anegada Passage; BR: Barracuda Rise; TR: Tiburon Rise. (red circles: location of possible major earthquakes responsible of the analyzed sedimentary event; white rectangle: studied area).

retrieved, with lengths ranging from $2.44 \mathrm{~m}$ to $7.31 \mathrm{~m}$ (mean: $4.77 \mathrm{~m}$ ). In this paper, we will focus on the northern part of the survey (between Basse-Terre and Nevis, Fig. 2).

Detailed magnetic susceptibility (MS) profiles were performed on all cores at the National Museum of Natural History (M.N.H.N.) in Paris, using a BARTINGTON ${ }^{\mathrm{TM}}$ MS2 contact sensor on split cores, at a $5 \mathrm{~mm}$ spatial resolution. MS is used here as an indicator of mineralogical content (e.g. Evans and Heller, 2003), and as a logging parameter for preliminary lateral correlations between cores. For grain-size analyses we used (in ISTerre Laboratory at Le Bourget du Lac) a MALVERN ${ }^{\mathrm{TM}}$ Mastersizer 2000 lasermicrogranulometer.

Radionuclides activities are used to date recent marine and lacustrine sediments (e.g. Nittrouer et al., 1979; Alvisi and Frignani, 1996; Appleby, 2002), mostly short-half life natural ${ }^{210} \mathrm{~Pb}$ and anthropogenic ${ }^{137} \mathrm{Cs}$. Atmospheric nuclear bomb tests released ${ }^{137} \mathrm{Cs}$ and ${ }^{241} \mathrm{Am}$ in the 1960s (maximum in 1962/1963). These radionuclides are also used to detect recent earthquake-related sedimentary disturbances (Chapron et al., 1999; Arnaud et al., 2002; Beck, 2009). Here, we also used excess (or non-supported) ${ }^{210} \mathrm{~Pb}$ activity (when showing a regular decay curve) to determine the sediment accumulation rate following the Constant Rate of Supply model (CRS; Noller, 2000) with additional control on sedimentation rates provided by ${ }^{137} \mathrm{Cs}$ and ${ }^{241} \mathrm{Am}$ activities 


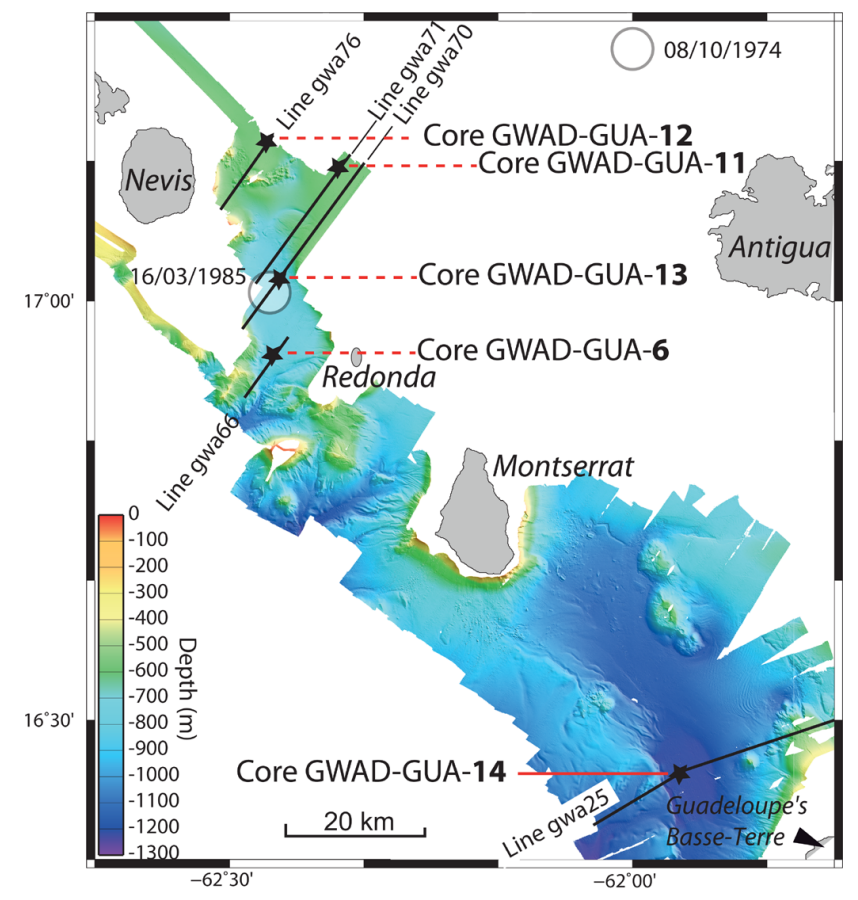

Fig. 2. Detailed bathymetry between Nevis and Guadeloupe islands. EM300 multibeam data from GWADASEIS cruise $(100 \mathrm{~m}$ of resolution). Location of seismic profiles shown in Fig. 3 and coring sites. (Area framed on Fig. 1) .

(Appleby et al., 1991; Appleby and Oldfield, 1992). Samples from cores GWAD-GUA-6, -11, -12, and -13, were taken every $5 \mathrm{~mm}$, within expected ${ }^{210} \mathrm{~Pb}$ decay interval (a few tens of centimeters) and selected isolated position to tests lack of activity. Samples were dried and processed in the subterranean site of the Laboratory of Climate and Environmental Sciences (L.S.C.E., Fréjus Tunnel, Modane), where they have been analyzed by $\gamma$ counting. Supported ${ }^{210} \mathrm{~Pb}$ was assumed to be in equilibrium with the in situ ${ }^{226} \mathrm{Ra}$ activity. Unsupported (excess) lead was calculated by subtracting ${ }^{226} \mathrm{Ra}$ from total ${ }^{210} \mathrm{~Pb}$.

\section{Evidence for systematic transfer of hemipelagic/ holopelagic deposits towards deepest intra-arc basins}

Numerous active faults were identified in the seismic and bathymetric data between Nevis and Basse-Terre, some of them crossing the volcanic complexes (see Leclerc et al., 2010, and detailed mapping in Feuillet et al., 2010). As shown on Figs. 1 and 2, the interplay of volcanism and faulting produces a complex seafloor morphology, with several fault-bounded basins and valleys of different sizes, shapes and depth in the outer arc and along the active inner arc (the outer arc is made of eroded volcanic shelves recovered by carbonate platforms, Bouysse et al., 1990). Apart from shal- low area deposits (coral reefs building and associated benthic calcareous productions), the sediments of the investigated region (500 to $1200 \mathrm{~m}$ deep) generally consist of planktonic foraminifera, calcareous nannoplankton and minor siliceous plankton and deep-water benthic foraminifera. Volcanismderived components are added by means of ash falls (tephra layers), reworked debris and alteration products (Reid et al., 1996; Le Friant et al., 2008).

Several very high resolution seismic reflection profiles were acquired perpendicularly to faults between Basse-Terre and Nevis (Fig. 3 and location on Fig. 2). With a 12 to $15 \mathrm{~cm}$ expected theoretical vertical resolution (using a 1.6 to $2.0 \mathrm{~km} \mathrm{~s}^{-1} \mathrm{~V}_{p}$ velocity), the $3.5 \mathrm{khz}$ data were unable to image the most recent sedimentary units (less than $1 \mathrm{~m}$ thick). At this scale we identified on several profiles a systematic strong overthickening of sedimentary layers towards the deepest zones of fault-controlled basins (examples on Fig. 3a, b). This geometry implies very recent fault activity. Thus, according to the dominant "primary" depositional process (settling of planktonic material), a major "secondary" process appears to be driving the transfer of sediments (Beck et al., 2010). Such a situation and such a mechanism have been observed in front of a volcanic arc, with a similar redistribution between oceanic ridges and deeper floors (Dolan et al., 1989).

Two extreme scenarios can be invoked for the temporal distribution of this reworking process. Either the process is continuous (sweeping by bottom water dynamics), or the process is made of scarce instantaneous events with large reworking associated (mass wasting, debris-flow, grain-flow, turbidite). The concerned areas are far below wave base including during the strongest tropical storms and hurricanes, a discontinuous process is far more likely.

For this discussion, detailed relationships between faulting and sedimentary infilling were developed. Based on GWADASEIS surveys and previous studies, Feuillet et al. (2010) presented a detailed map of active faults between Nevis and Guadeloupe Islands. A pattern of SW-NE normal faults characterizes the area (Feuillet et al., 2010; Fig. 2); hanging walls are dominantly on the northeastern side.

\section{Identification of transparent sedimentary units directly associated to faulting}

Sedimentation in the basins is also characterized by the existence of almost acoustically transparent sedimentary layers and lenticular bodies (labeled as hmg on Fig. 3a, c), intercalated between acoustically stratified levels. Their thickness decreases rapidly towards the basin slopes (Fig. 3a, b). We also identified such sedimentary layers on active normal fault hanging walls at the base of the scarps (Fig. 3c and Fig. 4; labeled E). Such transparent bodies (with thicknesses up to several tens of meters) have been described and interpreted by different authors as the result of huge sedimentary 

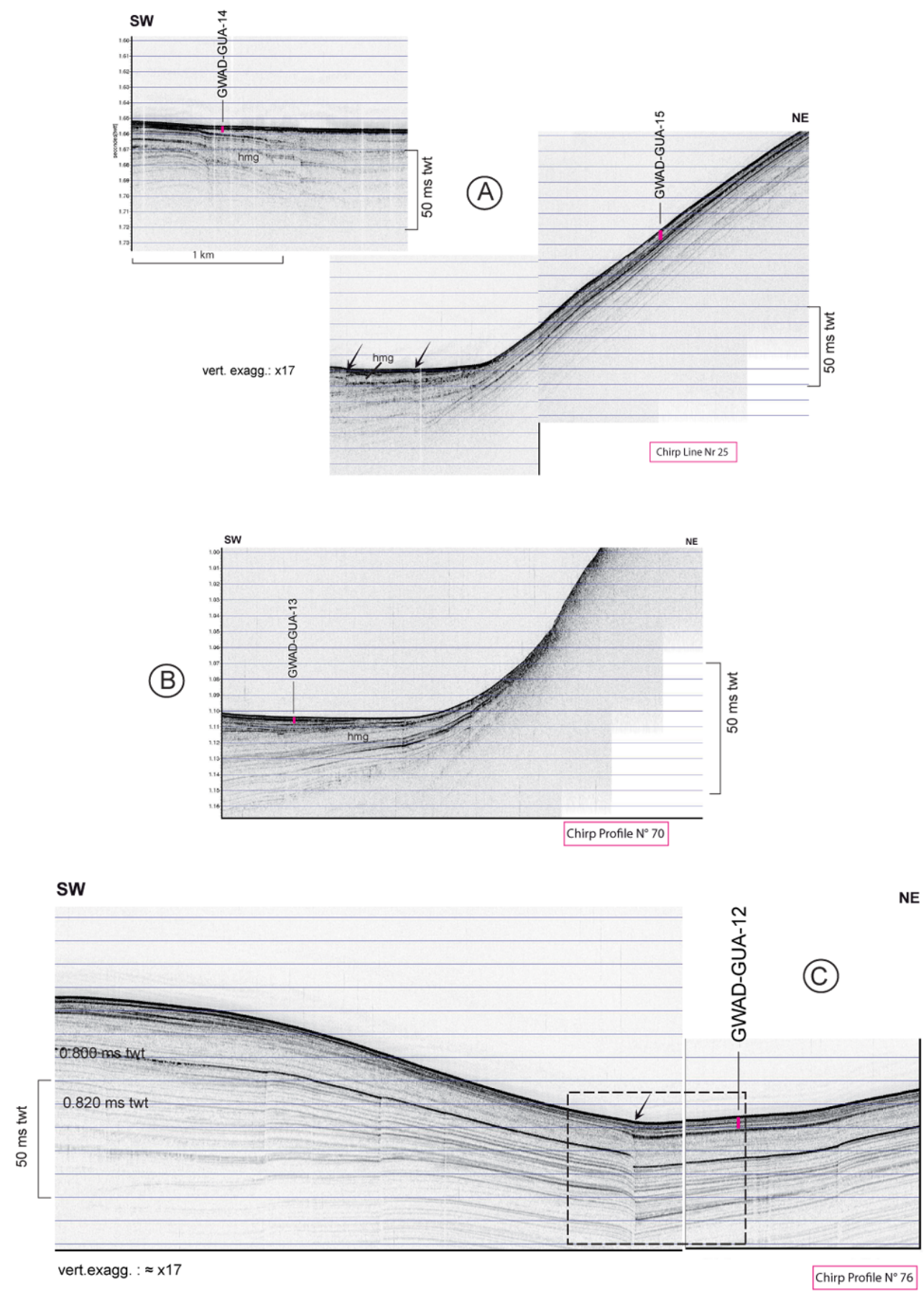

Fig. 3. Portions of VHR (chirp) seismic profiles (location on Fig. 2) and location of analyzed cores. Profiles 25 (A right) and 70 illustrate overthickening in deep troughs and associated erosion of submarine slopes and heights. Profiles 25 (A left) and 76 (black arrows) show a compensation of vertical faults offsets by specific (homogenous) deposits. (hmg: homogenites).

reworking induced by tsunami, or by a combination of earthquake and tsunami/seiche effects that are known both in marine and lacustrine settings (Kastens and Cita, 1981; Cita and Rimoldi, 1997; Chapron et al., 1999). Armijo et al. (2005) have observed similar abrupt changes in sedimentary units thickness between the footwalls and the hanging walls of active faults in the Marmara sea. In the Marmara example, by combining $3.5 \mathrm{kHz}$ profiles and giant piston cores data, Beck et al. (2007) have demonstrated that the total thickness difference corresponds to the accumulation of separate 


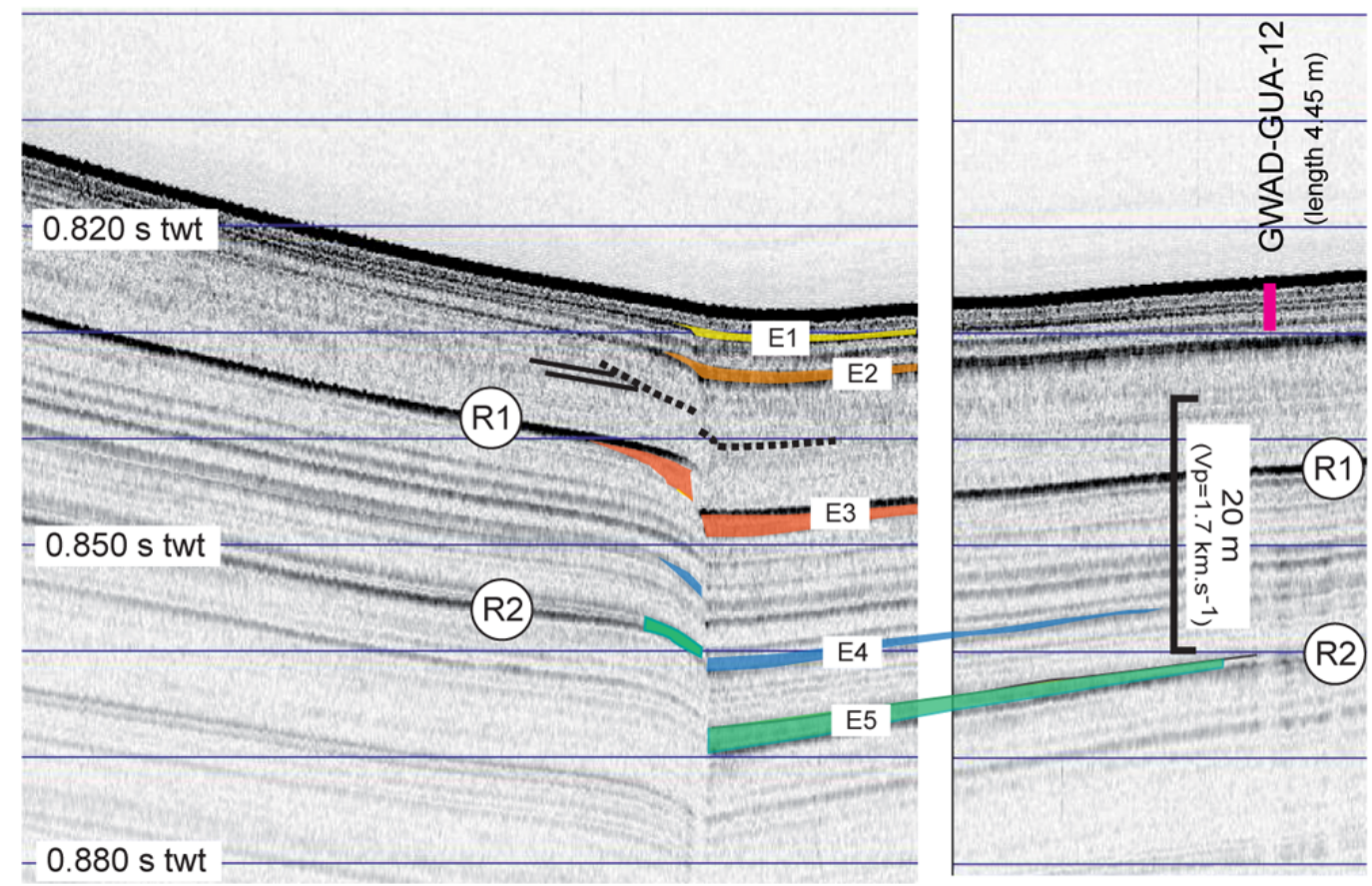

Fig. 4. Close up of profile 76 (location on Fig. 3c) displaying inferred co-seismic layers. R1 and R2 are major reflectors (possible tephra layers); E1 to E5 are inferred co-seismic sedimentary events. Two different situations may be distinguished with the used resolution: either an occurrence only on hanging wall, or an occurrence on both sides of the fault with an abrupt thickness increase on the hanging wall. Local collapse of the footwall may be observed (E3 and dashed line).

instantaneous sedimentary events instead of continuous postseismic sedimentation with thicker series on the downthrown block.

\section{The topmost recent "homogenous" layer in the Nevis zone (coring data)}

Direct visual observations of the recovered cores indicate important differences in the topmost sediments between core GWAD-GUA-6 and cores GWAD-GUA-11 to 14 (Figs. 4 to 7). Core GWAD-GUA-6 (Fig. 5), collected in the NevisMontserrat area, is characterized by a vertical color change, occurring in the topmost $5 \mathrm{~cm}$, from red-brown to green in the rest of the core. Usually, the brown-green color change corresponds to the RedOx boundary between the oxic layer at the sediment/water interface and sub-anoxic layer within the sediment due to the early diagenesis, especially in (slow rate) hemipelagic deposits. Depending on the sedimentation rate and the organic carbon content, the oxic layer can extend from a few centimetres to around a meter (Lyle, 1983).

Unlike the core GWAD-GUA-6, cores GWAD-GUA-11, -12 , and -13 (Nevis-Montserrat area) and GWAD-GUA14 (Montserrat-Guadeloupe area) (location on Fig. 2) display at their top a particular homogenous sandy-silty layer, which will be referred hereafter as the "top sandy homogenite" (TSH). In the Nevis-Montserrat cores (Figs. 6, 7, and 8), this layer is greenish and calcareous, made of Foraminifera (Planktonic species and rare deep benthic species), calcareous nanoplankton and minor volcanic-derived grains (ferromagnesian minerals, feldspars). In the MontserratGuadeloupe area, the TSH is brownish due to high volcaniclastic content, but has a similar texture. The lower parts of the cores correspond to light grey and light greenish calcareous mud with intercalated turbidites (few $\mathrm{cm}$ to $15 \mathrm{~cm}$ thick), displaying normal graded bedding, or lacking clear vertical evolution (similar to the top homogenous layer). In Cores GWAD-GUA-11 to -14 we observed a few $\mathrm{cm}$ of brownish hemipelagic mud just below the TSH, suggesting that the latter has capped the RedOx interface very recently. The TSH has a thickness of around $25-35 \mathrm{~cm}$ but can increase up to $2 \mathrm{~m}$ within core GWAD-11 (Fig. 8).

In order to demonstrate this interpretation, the presence of short-lived radionuclides was investigated; results are shown in Figs. 6 to 8; the top of Core GWAD-GUA-6 (Fig. 5) was also checked as expected to represent a "normal" reference situation.

For Core GWAD-GUA-6 (Fig. 5), the brownish topmost sediments represent a very thin layer, whose thickness may be explained partly by coring disturbance (compaction ?), and/or by a slow sedimentation; nevertheless, three samples yielded activities indicating that these topmost sediments include the Atmospheric Nuclear Experiments (ANE) ${ }^{137} \mathrm{Cs}$ 


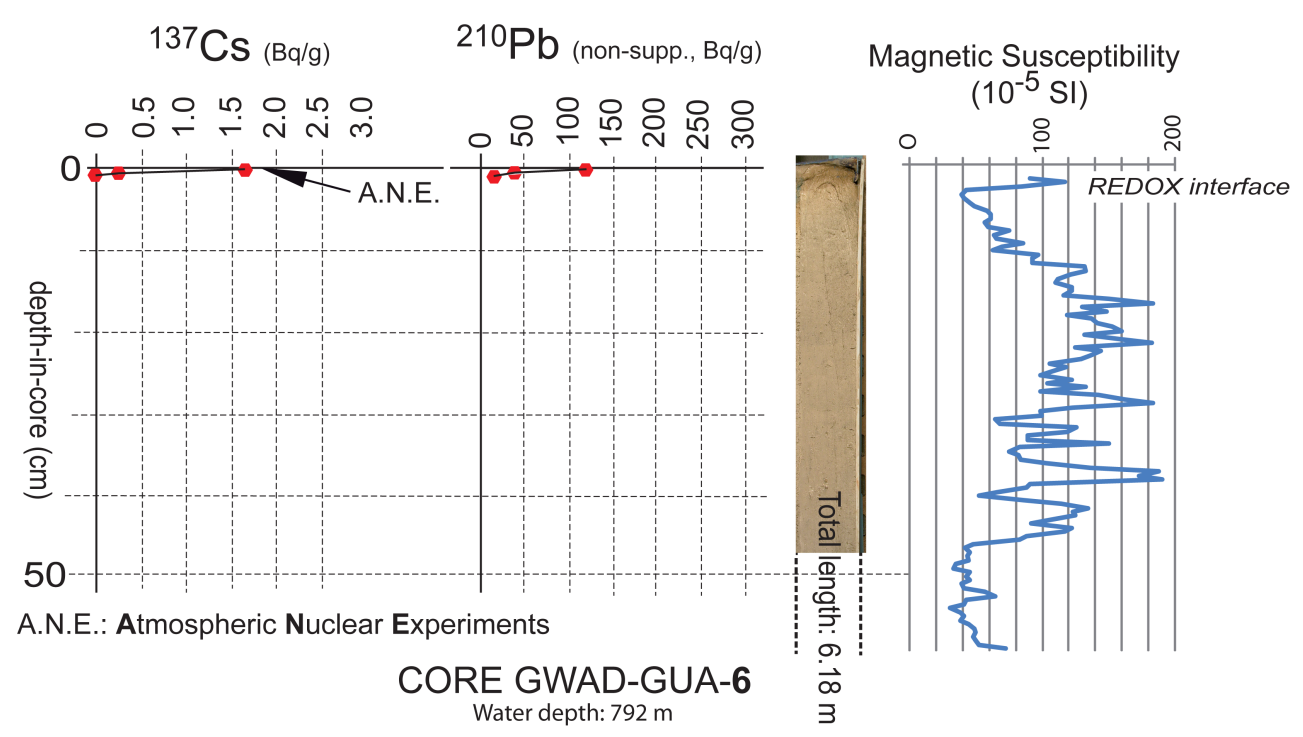

Fig. 5. Radionuclides and magnetic susceptibility profiles of Core GWAD-GUA 6. Only the brownish top $5 \mathrm{~cm}$ were samples as supposed to represent the RedOx interface of a slow hemipelagic sedimentation. A slight coring-induced compaction and/or a slight erosion cannot be discarded.

peak. ${ }^{210} \mathrm{~Pb}$ activity is also characteristic of deposits from the last decade. For Cores GWAD-GUA-12 and -13 (Figs. 6 and 7), sampling could be more complete and clearly illustrate the ANE peak (around 1962/1963 AD) and the decrease of ${ }^{210} \mathrm{~Pb}$ activity.

For Cores GWAD-GUA-11, 12 and -13 (Figs. 6, 7 and 8), samples from the TSH do not show the presence of radionuclides activity. The TSH thickness from core GWAD-GUA11 being largely higher than the $3.5 \mathrm{kHz}$ theoretical resolution, we consider that the composition and texture of such a layer correspond to transparent levels identified deeper in cores on $3.5 \mathrm{kHz}$ profiles (Fig. 3a, c, Fig. 4). Thus, the results strengthen the hypothesis that in cores GWAD-GUA$11,-12$, and -13 , the TSH observed in the topmost sediments is a unique instantaneous deposit which has recently capped the normal RedOx interface.

In Core GWAD-GUA- 11 case, the decrease of ${ }^{210} \mathrm{~Pb}$ activity below the base of the TSH (Fig. 8) could indicate a slight reworking (drag and mixing) of the hemipelagic mud by the base of sandy grain flow.

The basal limit of the TSH and the RedOx boundary clearly appears on the MS profiles (Figs. 6, 7, and 8). Preliminary grain-size analyses performed on Core GWAD-GUA13 (Fig. 9) also underline the differences. The "top sandy homogenite" (TSH) contains a significant silty-clayey content which favours an instantaneous reworking; the apparent sorting of a fine sand dominant content is related to the initial specific sizes of the transported fraction rather than to a mechanical sorting process. Nevertheless, complete investigations (content and texture, base-to-top evolution) are needed to understand the precise depositional processes.

\section{Recent occurrence of a major depositional event (sandy homogenite) in the Nevis-Montserrat- Guadeloupe area}

Based on the radionuclides activity profiles we constructed the (time-) correlations for the three sites cored in the NevisMontserrat area (Fig. 10). The base of the TSH is also underlined by magnetic susceptibility (MS) curves, which allows correlations in deeper parts of the cores. These correlations do not necessarily imply lateral (stratigraphic s.s.) continuity between the different sites, and the highest thickness is observed in the shallowest site (Core GWAD-GUA11). As mentioned in previous investigations, homogenites may be "ponded" in separated depressions as mapped in Central Mediterranean for the "Minoan" event (e.g. Kastens and Cita, 1982). The differences in MS values for the RedOx level (e.g. Cores GWAD-GUA-12 and -13) may be related to different stages of diagenesis and/or to some slight reworking. The slow "normal" early diagenetic evolution may also have been modified by homogenite arrival (cf. Demory et al., 2005). A similar interpretation may be proposed for the top of Core GWAD-GUA-14 where MS is higher in the TSH due to a higher content in volcanic debris. Because this core was taken in the Montserrat-Guadeloupe area (Fig. 2), questions arise about its correlation with the three cores from the Nevis-Montserrat area; one might wonder whether the sedimentary reworking event of Cores GWAD-GUA-11, -12, and -13, did occur in Core GWAD-GUA-14. The presence of such a correlation would imply the occurrence of a broad, regional scale, seismic event.

The age of the "top sandy homogenite" may be discussed based on the Nevis-Montserrat cores data. In the three sites, 

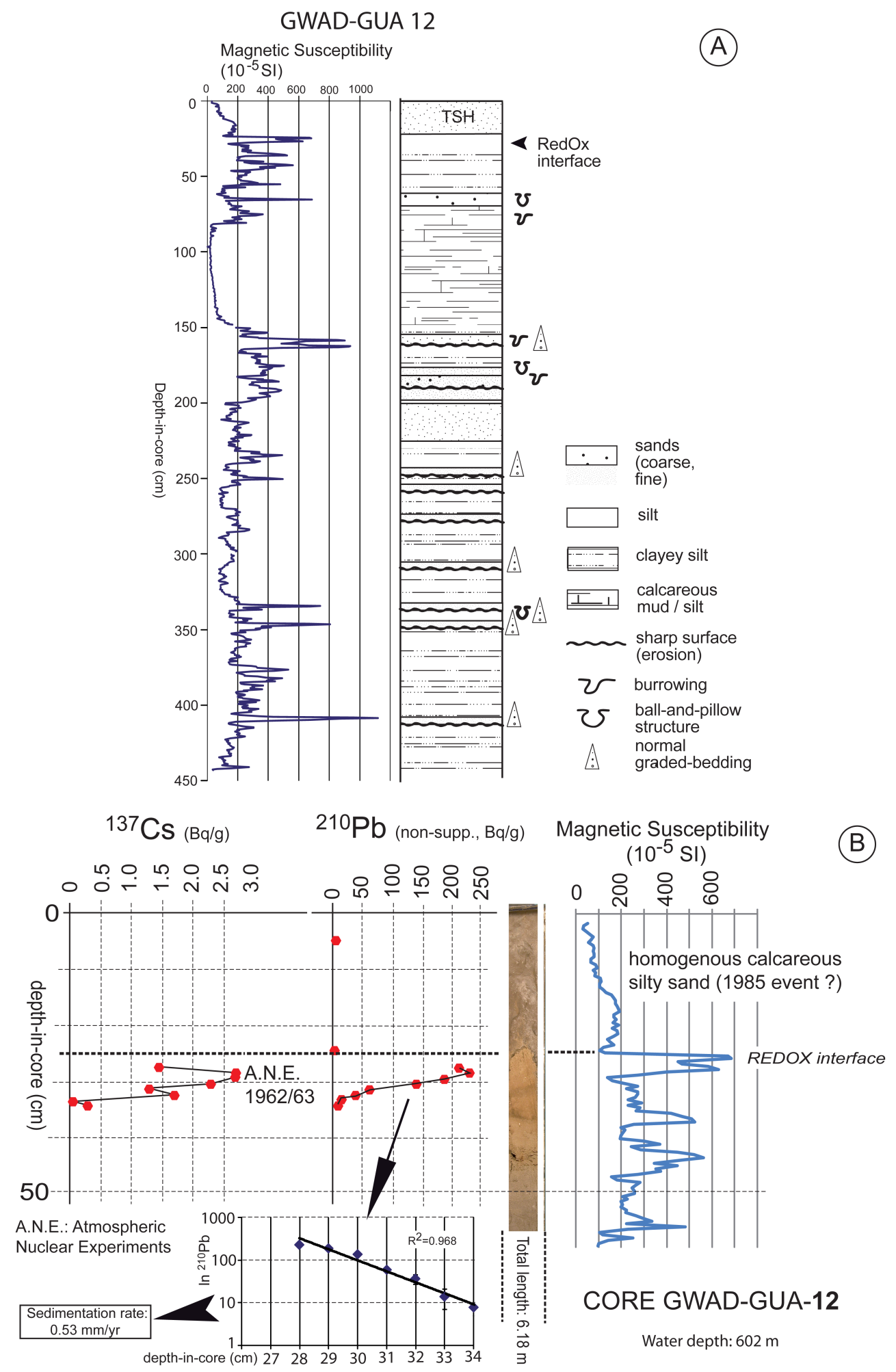

Fig. 6. Lithology, magnetic susceptibility, and radionuclides profiles of Core GWAD-GUA 12. (A) simplified lithology and magnetic susceptibility profile; (B) detail of the top $50 \mathrm{~cm}$ and radionuclides profiles. The radionuclides activities indicate that the brownish part between 25 and $35 \mathrm{~cm}$ represents the recent RedOx interface of a slow hemipelagic sedimentation. The ${ }^{210} \mathrm{~Pb}$ decrease $\left(\ln .{ }^{210} \mathrm{~Pb}\right.$ activity vs. depth; lower graph) is used to estimate the sedimentation rate in the concerned hemipelagic interval. 


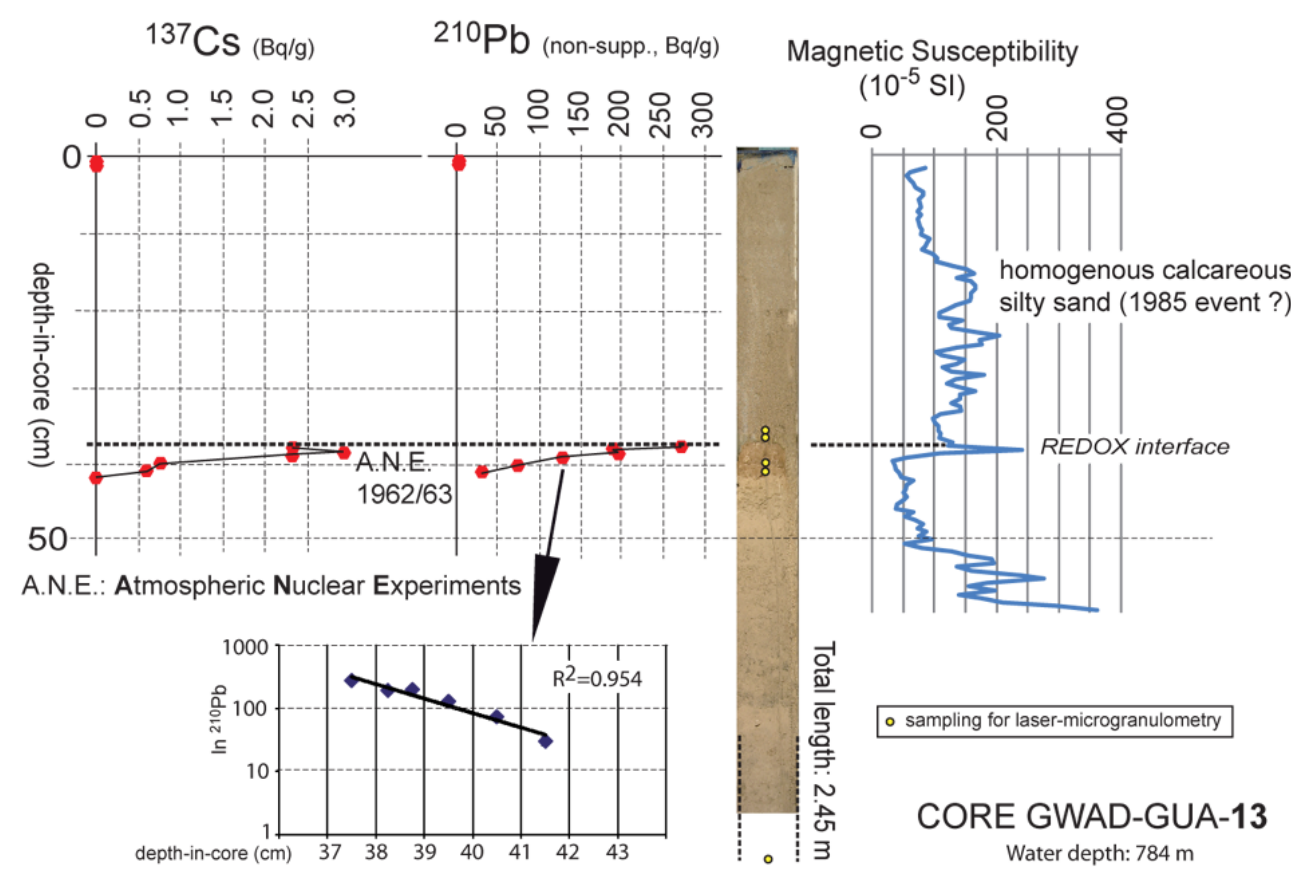

Fig. 7. Radionuclides and magnetic susceptibility profiles of Core GWAD-GUA 13. The radionuclides activities indicate that the brownish part between 37 and $42 \mathrm{~cm}$ represents the recent RedOx interface of a slow hemipelagic sedimentation. The ${ }^{210} \mathrm{~Pb}$ decrease $\left(\mathrm{ln} .{ }^{210} \mathrm{~Pb}\right.$ activity vs. depth; lower graph) is similar to Core GWAD-GUA 12's profile (Fig. 6b).

the idendification of the ANE related ${ }^{137} \mathrm{Cs}$ peak indicates a post-1962 age. For Cores GWAD-GUA-11 and -12, the ${ }^{210} \mathrm{~Pb}$ profiles display a decrease just below the base of the sandy homogenite; this difference from a normal situation (maximum activity at the sediment-water interface) suggests that part (few mm?) of the underlying hemipelagic sediments was removed. The initial profile probably reached a higher activity. Based on these results, and the slight removal of material below TSH we infer that it was most probably deposited after 1970

The ${ }^{210} \mathrm{~Pb}$ profile of Core GWAD-GUA-12 (Fig. 6a, b) was used to estimate the sedimentation rate of the fine-grained hemipelagic calcareous mud. The values we obtain are $0.53 \mathrm{~mm} \mathrm{yr}^{-1}$, close to that deduced from Core GWADGUA-13. This sedimentation rate appears much higher than the $0.023 \mathrm{~mm} \mathrm{y}^{-1}$ mean total rate calculated by Le Friant et al. (2008) in a borehole $55 \mathrm{~km}$ south-west of Montserrat. This result also differs from the value calculated in abyssal Pleistocene-Holocene hemipelagic sedimentation in front of the Arc where a $0.013 \mathrm{~mm} \mathrm{yr}^{-1}$ rate was found (ODP Site 672; Mascle, Moore et al., 1988). These differences may be explained by the fact that these very low rates are from deep sites far from the arc which is the main terrigenous source, and/or by a very low compaction in the succession analyzed here. For the following, a $0.5 \mathrm{~mm} \mathrm{yr}^{-1}$ rate will be tentatively extrapolated downcore and used to estimate time intervals between homogenite/turbidites.
We interpret the TSH following the specific depositional process of homogenites associated to seismo-turbidites (earthquake, and seiche effect) as defined for the Sea of Marmara and other marine or lacustrine basins (Beck et al., 2007; Chapron et al., 1999; e.g. in Beck, 2009). In the concerned area, two major earthquakes may have promoted major sedimentary reworking, the 8 October $1974\left(M_{\mathrm{w}}=7.4\right)$ and the 16 March $1985\left(M_{\mathrm{w}}=6.3\right)$. The former occurred within the caribbean plate at about $30 \mathrm{~km}$ depth. Its focal mechanism as well as the distribution of aftershocks revealed a rupture of a SE-dipping normal fault at the base of the crust (Mc Cann et al., 1982). The latter earthquake was smaller but shallower and occurred along the Redonda fault system (Feuillet et al., 2010). Given its depth and magnitude, the 1974 earthquake may have affected a much larger area than the 1985 earthquake. The 1974 earthquake was felt with an intensity of VI in Guadeloupe not far from the core GWAD-GUAD 14. The 1985 event was felt with an intensity of MSK IV, corresponding to a limited acceleration (between 7 and $15 \mathrm{mg}$ following the attenuation law calculated by Beauducel et al., 2011) probably not sufficient to promote a large scale sedimentary reworking (between Nevis and Guadeloupe). 


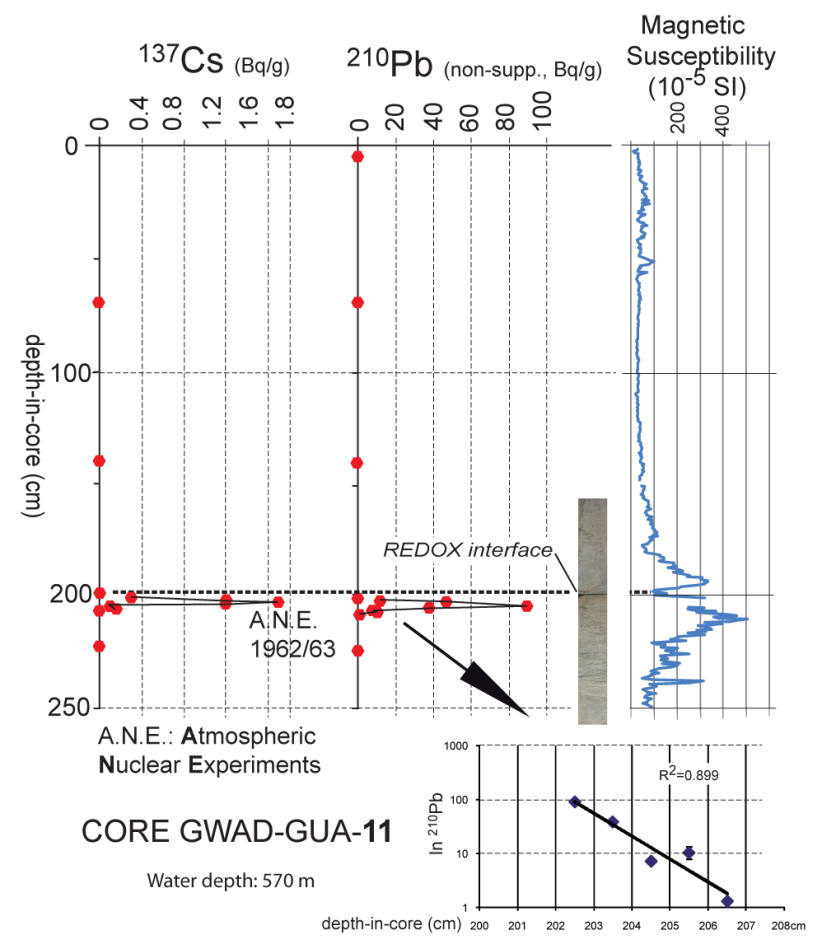

Fig. 8. Radionuclides and magnetic susceptibility profiles of Core GWAD-GUA 11. The radionuclides activities indicate that the yellowish level between 200 and $215 \mathrm{~cm}$ represents the recent RedOx interface of a slow hemipelagic sedimentation. The overlying $2 \mathrm{~m}$ of homogenous silty sand (referred within text as Topmost Sandy Homogenite/TSH) recently capped this RedOx interface; its thickness is much higher than the resolution of the used seismic imaging. The ${ }^{210} \mathrm{~Pb}$ decrease $\left(\ln .{ }^{210} \mathrm{~Pb}\right.$ activity vs. depth; lower graph) is similar to Core GWAD-GUA 12's profile (Fig. 6b).

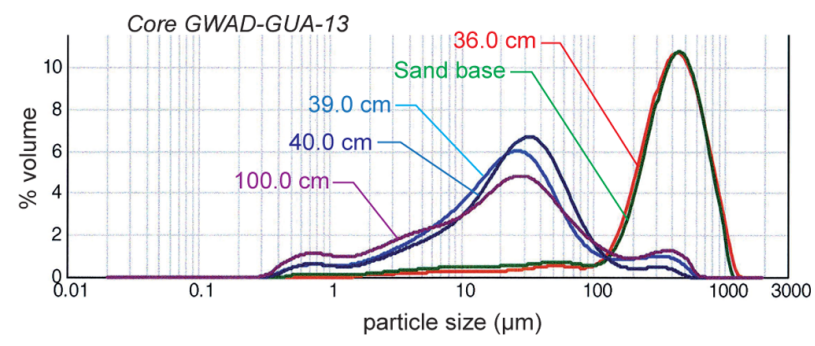

Fig. 9. Compared grain-size distributions of upper homogenite and hemipelagic sediments (MALVERN ${ }^{\mathrm{TM}}$ laser microgranulometer data).

On Fig. 10, we compare and correlate magnetic susceptibility of all analyzed cores including Core GWAD-GUA-14 from the Montserrat-Guadeloupe area about $70 \mathrm{~km}$ south of Cores GWAD-GUA-11 to -13 zone. Part of the main parameters for potential mass wasting triggering - magnitude, distance from epicentral area, slopes dip - seem compatible with a larger extension of the reworking event and the occurrence of the TSH in the Core GWAD-GUA-14 zone.
7 Relationship between "homogenites" and co-seismic faults offsets: temporal extrapolation of coring results

On several profiles, acoustically transparent "homogenites" appear directly associated to faulting, as on lines 25 and 76 (Fig. 3a, c; Fig. 4). We consider these layers as co-seismic for two reasons: (i) their layering and texture imply that they represent instantaneous deposits (cf. TSH coring results), (ii) they were deposited on the fault hanging-wall at the base of the normal fault scarp or within normal fault-controlled basins. The analyzed portions of Line 76 (Figs. 3c and 4) allow to discriminate "homogenites" offset without thickness changes (as schematized on Fig. 11, case A) from "homogenites" that are visible only on the hanging wall side or those displaying a difference in thickness between hanging wall and footwall (Fig. 11, case B2 and B1). Because two successive "homogenites" occur separated by a continuous hemipelagic accumulation, a sedimentation rate may be applied to the latter (excluding instantaneous sedimentary events), as proposed by Adams (1990) to estimate the time elapsed between two turbidites. Here, in order to reconstruct a succession of sedimentary events in one site (Core GWADGUA-12, Figs. 3c and 4), we combine the seismic data that evidence the major events with the core data in which minor reworking events were identified (e.g. Fig. 6a). The later ones permit to estimate the relative proportion of hemipelagic continuous deposit vs. reworking events for the intervals separating two transparent layers ("homogenites") in the seismic profiles.

Although our approach may appear similar to previously published analyses of subaqueous faulting and associated seismic hazards (Bull et al., 2006; Barnes and Pondard, 2010), differences have to be underlined. In the cited works, vertical components of faulting are estimated from the displacements of isochronous surfaces (dated from Late Quaternary HR seismic stratigraphy and/or coring) correlated from hanging wall to footwall, and assuming that all or part of the measured offsets are co-seismic. Barnes and Pondard (2010) distinguish two mean sedimentation rates preserving vs. not preserving fault scarps. Here, sedimentological data permitted to directly indentify co-seismic instantaneous deposits and, at the same time, to measure the associated sea floor offset.

Considering the hanging wall side, a preliminary estimate of the co-seismic increments on the vertical component of the active fault imaged on Line 76 (Core GWAD-GUA-12 Site, squared part of Figs. 3c, 4) may be proposed:

- 5 events (4 intervals as the upper event is top-limited by the water/sediment interface),

- a total thickness of $32 \mathrm{~m} \mathrm{(40} \mathrm{ms} \mathrm{t.w.t.} \mathrm{with} 1.6 \mathrm{k} \mathrm{s}^{-1}$ velocity),

- a $16.8 \mathrm{~m}$ thickness of intercalated hemipelagic sediments (total minus $8 \mathrm{~m}-10 \mathrm{~ms}$ twt - for $\Sigma$ transparent 


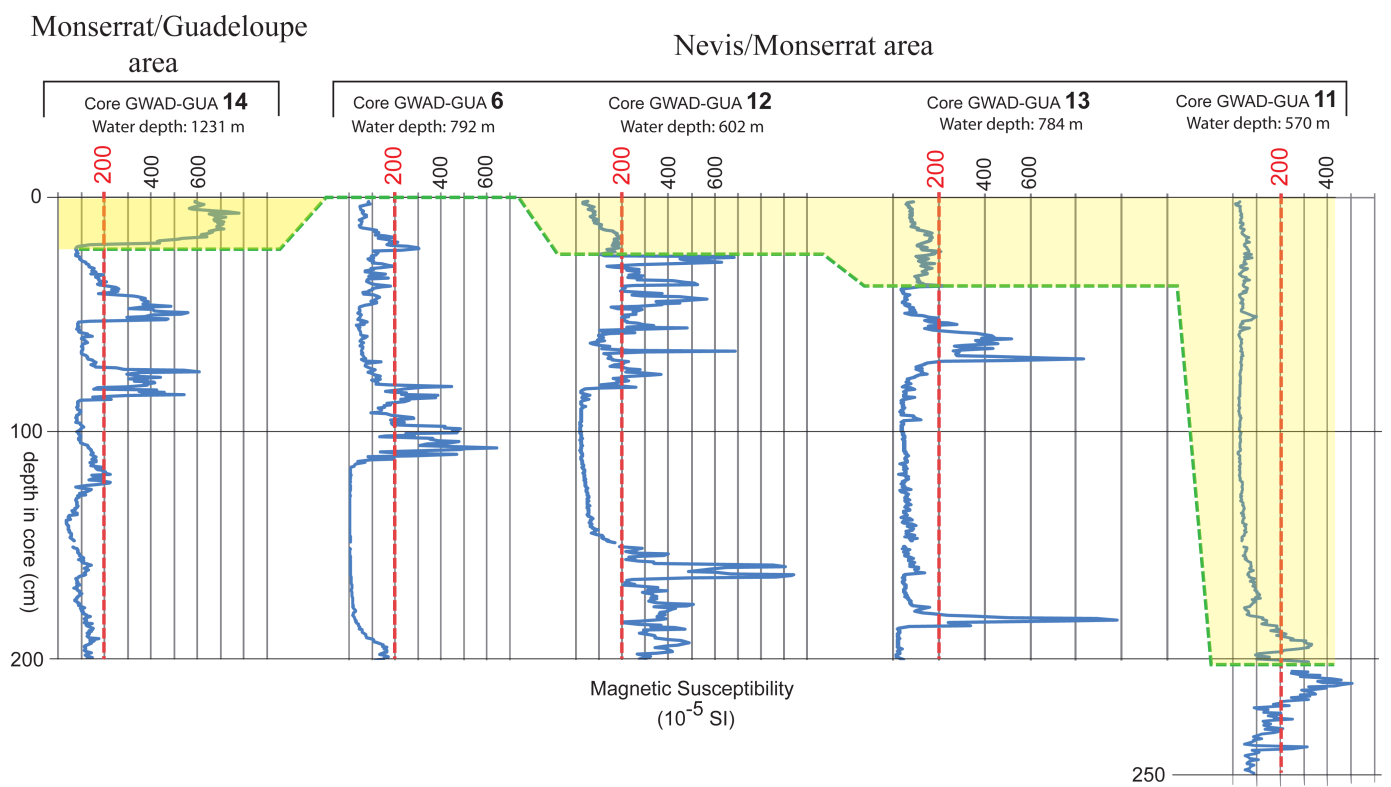

Fig. 10. Correlation of recent homogenite base between cores GWAD-GUA 11 to GWAD-GUA 14.

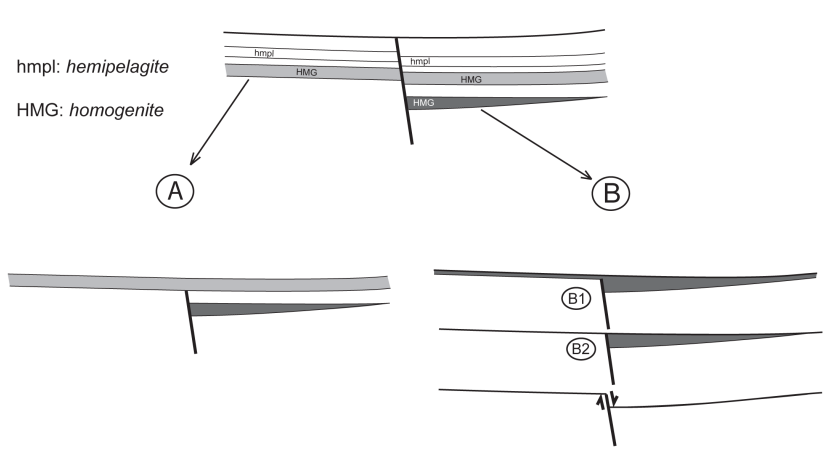

Fig. 11. Sketch of sedimentation and faulting in Core 12 area (Profile 76). In case A, hemipelagites ("background" sediments) and a homogenite are offset after their deposit; the homogenite does not appear related to the local active fault but may be related to a seismic triggering from a farther area; the observable offset is not necessarily co-seismic. In case $\mathrm{B}$, the homogenite (instantaneous deposit issued from mass wasting) is contemporaneous of an offset; "geometrical" compensation may be partial (B1) or complete (B2); the observable offset is co-seismic.

layers, and minus $30 \%$ of the rest corresponding to the average proportion of instantaneous deposits detected in cores),

- a $0.5 \mathrm{~mm} \mathrm{y}^{-1}$ sedimentation rate in hemipelagic sediment (deduced from ${ }^{210} \mathrm{~Pb}$ decay) representing about $34000 \mathrm{yr}$. This has to be taken as a minimum value as the mean sedimentation rate of hemipelagites for the whole core may be lower; future chronological constrains (AMS ${ }^{14} \mathrm{C}$ on selected Forams, in process) will precise.
Since the deposits are recent, no or little compaction has to be taken in account (no "back stripping" procedure) to reconstruct initial thicknesses and fault offset.

This calculation leads to a $6500 / 7000 \mathrm{yr}$ mean recurrence interval for major events associated to a significant ( $\geq$ theoretical seismic resolution of $12 \mathrm{~cm}$ ) vertical component offset. Intercalated "events", that are not necessarily related to local origin, include transparent layers visible on the seismic profile plus thinner turbidites/homogenites detected in cores. Their mean recurrence interval is comprised between 5 and 8 centuries. We must underline that these results have to be taken as a first approximation (possible underestimation of sonic velocity and overestimation of mean sedimentation rate), and only concern one section of one unique fault.

With respect to co-seismic offsets (vertical component), the values that we can derive from seismic data (up to about $3 \mathrm{~ms}$ twt; Figs. $3 \mathrm{c}$ and 4) are in fair agreement with the TSH thicknesses $(25 \mathrm{~cm}$ to $2 \mathrm{~m})$ from the cores. Thus these values are our preferred estimates for vertical offsets associated to major events.

Between inferred co-seismic deposits no significant interseismic (slow) slip could be detected (isopach accumulation across fault). This differs from results from another subaqueous fault survey (El Pilar fault, South-Caribbean) where both high resolution imaging and GPS measurements indicate a dominantly non co-seismic slip (Jouanne et al., 2010; Maarten et al., 2010). 


\section{Conclusions and perspectives}

A major post-1970 sedimentary event (mass wasting, gravity re-deposition and homogenization) has been detected and characterized in the Nevis-Montserrat area. We inferred that this particular layer was triggered by the 8 October 1974 or 16 March 1985 "Redonda" earthquakes, the most likely by the 1974 event. We identified a succession of homogenous sedimentary units (up to few $\mathrm{m}$ thick) in very high resolution seismic profiles $(3.5 \mathrm{kHz})$ over an approximate duration of $34000 \mathrm{yr}$. Some of these sedimentary bodies clearly appear associated to local faulting offsets. They were instantaneously deposited on the fault-hanging wall at the base of the scarp and may be thick enough to "obliterate" the coeval co-seismic scarp.

In terms of contribution to seismic hazard assessment, these results concern a regional paleoseismic archive lasting a few thousands years, and thus permitting a good frequency estimation. Our study shows that by combining very high resolution seismic profiling and coring, we are able to estimate time distribution of major co-seismic offsets along active faults together with the amounts of their vertical component (co-seismic increment up to $2 \mathrm{~m}$ in the hereanalyzed site). Inter-seismic time intervals are estimated using a sedimentation rate deduced from ${ }^{210} \mathrm{~Pb}$ decrease curve $\left(0.5 \mathrm{~mm} \mathrm{yr}^{-1}\right)$. The specificity of our approach is that we are able to take into account both minor reworking events observed on cores and major ones imaged by VHR seismicreflection. To estimate the corresponding magnitudes, the along-strike horizontal lengths of the rupture must be known and thus a detailed time/space evolution of faulting is needed for a defined area.

These additional data can be obtained using denser seismic grids coupled with more and longer cores. In order to improve accuracy and statistical validation, each separate active fault trace should be investigated (cf. Bull et al., 2006).

More detailed sedimentological characterization of the sediments will be of interest, in particular the determination of specific texture through Anisotropy of Magnetic Susceptibility (AMS) as done in the case of the Sea of Marmara (Campos et al., 2011). Advanced geotechnical characterization of the initial deposits, namely the checking of criteria for slope failure (Stegmann et al., 2007; Strasser et al., 2006), might help in defining the energy associated to the local seismic events.

Acknowledgements. We are grateful to the captains, officers and crew of $\mathrm{R} / \mathrm{V}$ LE SÛROIT(IFREMER-GENAVIR), with special thanks to the coring technical team. We thank Bernard Mercier de Lepinay (Géosciences Azur) who helped for the Chirp processing. The cruise was supported by the ANR CATELL CNRS-INSU program; post-cruise funding (laboratory core processing and measurements) was also added by INSU-CNRS funding through specific grants and involved CNRS-associated laboratories (Sciences de la Terre, M.N.H.N., Paris; ISTerre, Grenoble University).
We sincerely acknowledge Alessandro Michetti and an anonymous reviewer whose comments contributed to significantly improve the initial manuscript.

Edited by: D. Pantosti

Reviewed by: A. M. Michetti and another anonymous referee

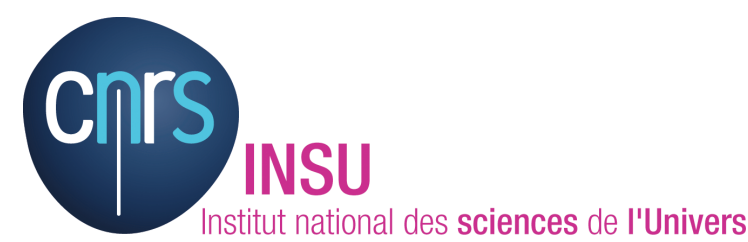

The publication of this article is financed by CNRS-INSU.

\section{References}

Adams, J.: Paleoseismicity of the Cascadian subduction zone: evidence from turbidites, off the Oregon-Washington margin, Tectonics, 9, 4, 569-583, 1990.

Alvisi, F. and Frignani, M.: ${ }^{210} \mathrm{~Pb}$-derived sediment accumulation rates for central Adriatic Sea and crater lakes Albano and Nemi (central Italy), Palaeoenvironmental Analysis of Italian Crater Lakes and Adriatic Sediments, Mem. Ist. Ital. Idrobiol., 55, 303320, 1996.

Appleby, P. G.: Chronostratigraphic techniques in recent sediments, in: Tracking Environmental Change Using Lake Sediments, edited by: Last, W. M. and Smol, J. P., Basin Analysis, Coring; and Chronological Techniques, Developments in Paleoenv R, Kluwer Academic Publishers, 171-203, 2002.

Appleby, P. G. and Oldfield, F.: Application of ${ }^{210} \mathrm{~Pb}$ to sedimentation studies, in: Uranium-series Disequilibrium, edited by: Ivanovitch, M., and Harmon, R. S., Appl. Earth. Mar. Environ. Sci., 731-778, 1992.

Appleby, P. G., Richardson, N., and Nolan, P. J.: ${ }^{241}$ Am dating of lake sediments, Hydrobiologia, 214, 35-42, 1991.

Armijo, R., Pondard, N., Meyer, B., Uçarkus, G., Mercier de Lépinay, B., Malavieille, J., Dominguez, S., Gutscher, M.A., Schmidt, S., Beck, C., Çagatay, N., Çakir, Z., Imren, C., Eris, K., Natalin, B., Özalaybey, S., Tolun, L., Lefèvre, I., Seeber, L., Gasperini, L., Rangin, C., Emre, O., and Sarikavak, K.: Submarine fault scarps in the Sea of Marmara pull-apart (North Anatolian Fault): Implications for seismic hazard in Istanbul, Geochem. Geophy. Geosy., 6, 6, Q06009, doi:10.1029/2004GC000896, 2005.

Arnaud, F., Lignier, V., Revel, M., Desmet, M., Beck, C., Pourchet, M., Charlet, F., Trentesaux, A., and Tribovillard, N.: Flood and earthquake disturbance of ${ }^{210} \mathrm{~Pb}$ geochronology (Lake Anterne, NW Alps), Terra Nova, 14, 225-232, 2002.

Barnes, P. M. and Pondard, N.: Derivation of direct on-fault submarine paleoearthquake records from high-resolution seismic reflection profiles: Wairau Fault, New Zealand, Geochem. Geophy. Geosy., 11, Q11013, doi:10.1029/2010GC003254, 2010.

Beauducel F., Bazin, S., Bengoubou-Valérius, M., Bouin, M.-P., Bosson, A., Anténor-Habazac, C., Clouard, V., and de Chabalier, J.-B.: Empirical model for rapid macroseismic intensities 
prediction in Guadeloupe and Martinique, C.R. Geoscience, 343, 11-12, 717-728, doi:10.1016/j.crte.2011.09.004, 2011.

Beck, C.: Late Quaternary lacustrine paleo-seismic archives in north-western Alps: Examples of earthquake-origin assessment of sedimentary disturbances, Earth-Sci. Rev., 96, 327-344, 2009.

Beck, C., Feuillet, N., Reyss, J.-L., and GWADASEIS Scientific Party: Direct measurement of co-seismic fault activity through associated sedimentation: an example within the Lesser Antilles Arc., 18th International Sedimentological Congress, Mendoza, 2010.

Beck, C., Mercier de Lépinay, B., Schneider, J.-L., Cremer, M., Çaatay, N., Wendenbaum, E., Boutareaud, S., Ménot, G., Schmidt, S., Weber, O., Eris, K., Armijo, R., Meyer, B., Pondard, N., Gutscher, M.-A., and the MARMACORE Cruise Party: Late Quaternary co-seismic sedimentation in the Sea of Marmara's deep basins, Sediment. Geol., 199, 65-89, 2007.

Bouysse, P. and Westercamp, D.: Effets de la subduction de rides oceaniques sur r'évolution d'un arc insulaire: l'exemple des Petites Antilles, Bulletin de la Société Géologique de France, 2/3, 3-38, 1988.

Bouysse, P., Westercamp, D., and Andreieff, P.: The Lesser Antilles Island Arc, in: Proceedings of the Ocean Drilling Program, Scientific Results, edited by: Moore, J. C., Mascle, A., Taylor, E., Alvarez, F., Andreieff, P., Barnes, R., Beck, C, Behrmann, J., Blanc, G., Brown, K., Clark, M., Dolan, J., Fisher, A., Gieskes, J., Hounslow, M., McClellan, P., Moran, K., Ogawa, Y, Sakai, T, Schoonmaker, J., Vrolijk, P. J., Wilkens, R., and Williams, C., 110, 29-44, 1990.

Bull, J. M., Barnes, P. M., Lamarche, G., Sanderson, D. J., Cowie, P., Taylor, S. K., and Dix, J. K.: High-resolution record of displacement accumulation on an active normal fault: implications for models of slip accumulation during repeated earthquakes, J. Struct. Geol., 28, 1146-1166, 2006.

Campos, C., Beck, C., Crouzet, C., and Carrillo, E.: Characterization of Late Pleistocene-Holocene earthquake-induced "homogenites" in the Sea of Marmara through magnetic fabric, Implications for co-seismic offsets detection and measurements, Proceedings 2nd INQUA-IGCP-567 International Workshop on Active Tectonics, Earthquake Geology, Archaeology and Engineering, Corinth, Greece, 19-21, 2011.

Chapron, E., Beck, C., Pourchet, M., and Deconinck, J.-F.: 1822 earthquake-triggered homogenite in Lake Le Bourget (NW Alps), Terra Nova, 11, 86-92, 1999.

Cita, M. B. and Rimoldi, B.: Geological and geophysical evidence for a Holocene tsunami deposit in the eastern Mediterranean deep-sea record, J. Geodynam., 24, 1/4, 293-304, 1997.

DeMets, C., Jansma, P. E., Mattioli, G. S., Dixon, T. H., Farina, F., Bilham, R., Calais, E., and Mann, P.: GPS geodetic constraints on Caribbean-North America plate motion, Geophys. Res. Lett., 27, 437-440, 2000.

Demory, F., Oberhänsli, H., Nowaczyk, N. R., Gottschalk, M., Wirth, R. and Neumann, R.: Detrital input and early diagenesis in sediments from Lake Baikal revealed by rock magnetism, Global Planet. Change, 46, 1-4, 145-166, 2005.

Dolan, J., Beck, C., and Ogawa, Y.: Upslope deposition of extremely distal turbidites: an example from the Tiburon Rise, west-central Atlantic, Geology, 17, 990-994, 1989.

Evans, M. and Heller, F.: Environmental Magnetism. Principles and Applications of environmagnetics, International Geophysics Se- ries, 86, Academic Press, 299 pp., 2003.

Feuillet, N., Leclerc, F., Tapponnier, P., Beauducel, F., Boudon, G., Le Friant, A., Deplus, C., Lebrun, J.-F., Nercessian, A., Saurel, J.-M., and Clément, V.: Active faulting induced by slip partitioning in Montserrat and link with volcanic activity: New Insights from the 2009 GWADASEIS marine cruise data, Geophys. Res. Lett., 37, L00E15, doi:10.1029/2010GL042556, 2010.

Feuillet, N., Manighetti, I., and Tapponnier, P.: Arc parallel extension and localization of volcanic complexes in Guadeloupe, Lesser Antilles, J. Geophys. Res., 107, 2331, doi:10.1029/2001JB0003082002.

Feuillet, N., Tapponnier, P., Manighetti, I., Villemant, B., and King, G. C. P.: Differential uplift and tilt of Pleistocene reef platforms and Quaternary slip rate on the Morne-Piton normal fault (Guadeloupe, French West Indies), J. Geophys. Res., 109, B02404, doi:10.1029/2003JB002496, 2004.

Feuillet, N., Beauducel, F., Jacques, E., Tapponnier, P., Delouis, B., Bazin, S., Vallée, M., and King, G. C. P.: The $\mathrm{Mw}=6.3$, November 21, 2004, Les Saintes earthquake (Guadeloupe), Tectonic setting, slip model and static stress changes, J. Geophys. Res., 116, B10301, doi:10.1029/2011JB008310, 2011a.

Feuillet, N., Beauducel, F., and Tapponnier, P.: Tectonic context of moderate to large historical earthquakes in the Lesser Antilles and mechanical coupling with volcanoes, J. Geophys. Res., 116, B10308, doi:10.1029/2011JB008443, 2011b.

Jouanne, F., Audemard, F. A., Beck, C., VanWelden, A., Ollarves, R., and Reinoza, C.: Present-day deformation along the El Pilar Fault in eastern Venezuela: Evidence of creep along a major transform boundary, J. Geodynam., 51, 398-410, 2010.

Kastens, K. and Cita, M. B.: Tsunami-induced sediment transport in the abyssal Mediterrranean Sea, Geolog. Soc. Am. Bull., 92, 845-857, 1981.

Leclerc, F.: Fonctionnement des failles actives dans l'arc Antillais: apport des nouvelles campagnes à la mer GWADASEIS (2009) et BATHYSAINTES (2010), Implications pour l'aléa sismique et volcanique aux Saintes (Guadeloupe) et à Montserrat, MSc. Memoir, University of Paris VII, Institut de Physique du Globe de Paris, 2010.

Leclerc, F., Feuillet, N., and the GWADASEIS team, Active faulting induced by the slip partitioning in the Lesser Antilles arc., Geophys. Res. Abstr., EGU general Assembly, 12, 2010.

Le Friant, A., Lock, E. J., Hart, M. B., Boudon, G., Sparks, R. S. J., Leng, M. J., Smart, C. W., Komorowski, J. C., Deplus, C., and Fisher, J. K.: Late Pleistocene tephrochronology of marine sediments adjacent to Montserrat, Lesser Antilles, J. Geolog. Soc., 165, 279-289, 2008.

Lopez, A. M., Stein, S., Dixon, T., Sella, G., Calais, E., Jansma, P., Weber, J., and La Femina, P.: Is there a northern Lesser Antilles forearc block ?, Geophys. Res. Lett., 33, 2006.

Lyle, M. , The brown-green color transition in marine sediments: A marker of the Fe(III)-Fe(II) redox boundary., Limnol. Oceanogr., 28, 1026-1033, 1983.

Van Daele, M., Van Welden, A., Moernaut, J., Beck, C., Audemard, F. A., Sanchez, J., Jouanne, F., Carrillo, E., Malavé, G., Lemus, A., De Batist, M., Reconstruction of Late-Quaternary sea- and lake-level changes in a tectonically active marginal basin using seismic stratigraphy: The Gulf of Cariaco, NE Venezuela, Mar. Geol., 279, 37-51, 2010.

Mascle, A., Moore, J. C, and ODP Leg 110 Shipboard Scientific 
party: Taylor, E., Alvarez, F., Andréieff, P., Barbes, R., Beck, C., Behrmann, J., Blanc, G., Brown, K., Clark, M., Dolan, J.F., Fisher, A., Gieskes, J., Hounslow, M., McLellan, P., Moran, K., Ogawa, Y., Sakai, T., Schoonmaker, J., Vrolijk, P., Wilkens, R., and Williams, C.: Proceedings of the Ocean Drilling Program, Initial Reports (Part. A), ODP, 110, College Station, TX (Ocean Drilling Program), 1988.

McCann, W. R., Dewey, J. W., Murphy, A. J., and Harding, S. T.: A large normal-fault earthquake in the overriding wedge of the Lesser Antilles subduction zone: The earthquake of 8 October 1974, Bull. Seismol. Soc. Am., 72, 2267-2283, 1982.

McHugh, C., Seeber, L., Braudy, N., Cormier, M.-H., Davis, M. B., Diebold, J. B., Dieudonne, N., Douilly, R., Gulick, S. P. S., Hornbach, M. J., Johnson, H. E. III, Ryan Miskin, K., Sorlien, C., Steckler, M., Symithe, S. J., and Templeton, J.: Offshore sedimentary effects of the 12 January 2010 Haiti earthquake, Geology, 39, 8, 723-726, doi:10.1130/G31815.1, 2011.

Minster, J. and Jordan, T.: Present-day plate motions, J. Geophys. Res.-Atmos., 83, 5331-5354, 1978.

Nittrouer, C. A., Sternberg, R. W., Carpenter, R., and Bennett, J. T.: The use of $\mathrm{Pb}-210$ geochronology as a sedimentological tool: Application to the Washington continental shelf, Mar. Geol., 31, 297-316, 1979.
Noller, J. S.: Lead-210 Geochronology in Quaternary Geochronology: Methods Appl., Am. Geophys. Union, 115-120, 2000.

Reid, R. P., Carey, S. N., and Ross, D. R.: Late Quaternary sedimentation in the Lesser Antilles island arc, Geolog. Soc. Am. Bull., 108, 78-100, 1996.

Stegmann, S., Strasser, M., Anselmetti, F. S., and Kopf, A.: Geotechnical in situ characterisation of subaquatic slopes: The role of pore pressure transients versus frictional strength in landslide initiation, Geophys. Res. Lett., 34, L07607, doi:10.1029/2007GLO29881, 2007.

Strasser, M., Anselmetti, F. S., Fäh, D., Giardini, D., and Schnellmann, M.: Magnitudes and source areas of large prehistoric northern Alpine earthquakes revealed by slope failures in lakes, Geology, 34, 1005-1008, 2006.

Van Daele, M., Van Welden, A., Moernaut, J., Beck, C., Audemard, F. A., Sanchez, J., Jouanne, F., Carrillo, E., Malavé, G., Lemus, A., and De Batist, M.: Reconstruction of Late-Quaternary seaand lake-level changes in a tectonically active marginal basin using seismic stratigraphy: The Gulf of Cariaco, NE Venezuela, Mar. Geol., 279, 37-51, 2010. 